15th INTERNATIONAL HIMALAYA-KARAKORAM-TIBET WORKSHOP

\title{
The Central Asiatic (Tibet, Xinjiang, Pamir) petrological collections of Sven Hedin (1865-1952) - Swedish explorer and adventurer
}

\author{
Roberto F. Weinberg ${ }^{\mathrm{a}, 1}$, Owen R. Green ${ }^{\mathrm{b}, *}$ \\ anstitute of Earth Sciences, Uppsala University, Villavägen 16, Uppsala S-752 36, Sweden \\ ${ }^{\mathrm{b}}$ Department of Earth Sciences, Oxford University, Parks Road, Oxford OX1 3PR, UK
}

Received 19 February 2001; accepted 19 July 2001

\begin{abstract}
During a 42 year period (1893-1935), the Swedish explorer Sven Hedin led and co-ordinated four expeditions to remote and inhospitable parts of Central Asia (Tibet, Xinjiang, Pamir). Along with collaborators he collected a diverse collection of just under 3100 petrological specimens. Petrographic examples of high pressure metamorphic blueschists, mantle peridotites and serpentinites, granitoids, K-rich alkaline lavas, mylonites, and a range of clastic and fossil rich carbonate sedimentary rocks are present. This collection is a major asset for scientists studying the history of continental collision between India and Asia, and the uplift of the Tibetan plateau.

A spreadsheet listing all the samples collected during Hedin's first three expeditions into Tibet (commencing 1893, 1899, 1906) includes a brief description and location of each specimen, with additional information on the availability of thin sections. Samples are cross-referenced with the geographical position of Hedin's campsites indicated on maps published with his extensive reports. Most samples, and a number of thin sections, are available for loan from the Swedish Museum of Natural History, Stockholm. We also describe a smaller collection of specimens and thin sections from Hedin's fourth (1927-35, Sino-Swedish) expedition, currently housed at the Institute of Earth Sciences, Uppsala University. Hedin's career as an explorer, highlighting the geological significance of his work and the reasons that it has remained largely ignored by the majority of Himalayan and Central Asian researchers for so many years, is outlined. (C) 2002 Elsevier Science Ltd. All rights reserved.
\end{abstract}

Keywords: Petrological; Collections database; Central Asia exploration; Sven Hedin

\section{Introduction}

The Swedish explorer and adventurer Sven Hedin (Fig. 1) is arguably the greatest of late 19th and early 20th century Central Asiatic explorers. Hedin led and co-ordinated some of the most extensive surveys undertaken over inhospitable terrain during a forty year period, collecting, in addition to geological specimens, archaeological, ethnological, biological and meterological data. Individually, and in latter years with collaborators, he amassed and described an extensive petrographic collection. The largest proportion of this collection, 2214 specimens and 875 thin sections, is housed in the Swedish Museum of Natural History in Stockholm (see Appendix A), with a smaller collection of 543 thin sections available in the Institute of Earth Sciences, Uppsala University (see Appendix A). These thin sections and hand

\footnotetext{
* Corresponding author.

E-mail address: oweng@earth.ox.ac.uk (O.R. Green).

1 Present address: Department of Geology and Geophysics, Centre for Global Metallogeny, University of Australia, Nedlands WA 6907, Australia.
}

specimens have been the basis of many publications describing the geomorphology and geology of Xinjiang and Tibet (e.g. Norin, 1946).

The breadth of Hedin's interests is evident from his extensive and diverse publication record, and the numerous accounts of his travels reported in the journals of the Royal Geographical Society (London) and National Geographic (Washington) by Hedin and others. A list of his publications, in a commemorative volume of Geografiska Annaler (1935), coincided with celebrations for his 70th birthday. A cursory look at this and later biographies confirms that in addition to his extensive expedition reports and popular travelogues, Hedin also wrote biographies of the Russian explorer Nikolai Przhevalski (1839-1888), and the Chinese Nationalist's leader Chiang-Kai-shek (Hedin, 1891; 1939). A scientific and popular demand for his publications resulted in many works translated from Swedish, not only into German and English, but also French, Polish, Russian, Dutch, Italian, Norwegian, Finnish, Spanish, Serbian, Ukrainian, Yiddish and Japanese. Many of the artifacts collected during his early travels are still on display in the 


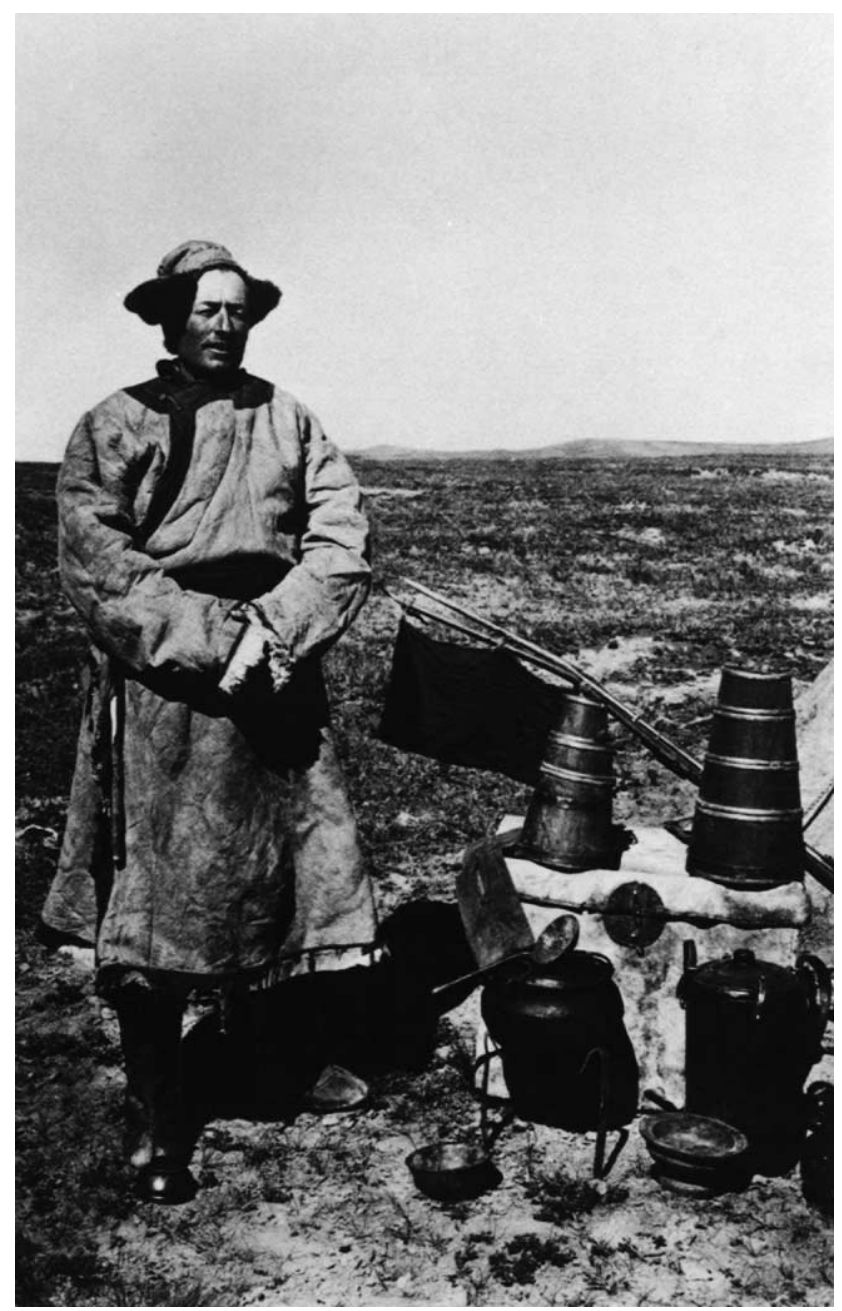

Fig. 1. Sven Anders Hedin (1865-1952). Pictured as a Mongolian pilgrim in camp approximately 100 years ago. Hedin's use of ethnic clothing was an attempt to foil the Tibetan authorities in an unsuccessful effort to reach Lhasa. Lucky to escape with his life and given a warning not to return, the patrol escorting him back to the border were convinced he was part of an advanced invasion force of Russian Cossacks.

Ethnological Museum in Stockholm, while an extensive collection of Lower Palaeozoic trilobites, collected during the Sino-Swedish expedition (Troedsson, 1937) is housed in the Museum of the Nanjing Institute of Palaeontology (Academia Sinica), China (see Appendix A).

In this paper we briefly describe the explorer's life, and his four main expeditions through Central Asia. Hedin's expeditions, lasting many years through winter and summer months, were to remote and inhospitable areas, combining high altitude and extreme weather conditions. Hedin frequently wore native clothing (Fig. 1), and on one excursion into Tibet, in an effort to avoid the authorities, disguised himself as a native Buryat Buddhist priest, going to the extremes of shaving his head, colouring his skin and wearing blue tinted Tibetan glasses to conceal his blue eyes. Collectively these details provide an insight into the explorer's personal determination to overcome adversity, and in his ability to adapt in unfavorable condi- tions, factors that undoubtedly resulted in his success. However, fate, politics and an element of personal ideology damaged his reputation, particularly amongst the influential and conservative British scientific establishment, resulting in his work, and in particular the geological collections, remaining largely ignored.

The extensive petrological collection housed in the Swedish Museum of Natural History has been catalogued and a spreadsheet database produced. It has been translated and edited from Swedish by one of us (RFW), and when viewed with copies of Hedin's expedition maps, provides a comprehensive data set for the accurate location of specimens and thin sections together with their availability. The spreadsheet can be examined on the Department of Mineralogy, Swedish Museum of Natural History web site at: http:// www.nrm.se/mi/welcome.html.en, following the page links.

\section{Hedin's early life}

Sven Anders Hedin was born in Stockholm on February 19th, 1865. He was the son of an architect, Ludwig Hedin (1826-1917), and Anne Westman (1838-1925). In 1886, at the age of 21, he travelled through Persia and Russian Central Asia, and on returning to Sweden enrolled at the University of Stockholm, determined to acquire the necessary skills to be an explorer - the vocation destined to be his life's work. For two years he studied geology, physics and zoology. On graduating he continued his education at Berlin University, studying palaeontology, historical geography and physical geography under Baron Ferdinand von Richthofen (1833-1905, himself a celebrated Asiatic explorer) and other leading professors.

In 1890 he interrupted his studies to make his first trip to Kashgar (Fig. 2, expedition route 1), crossing the Tien Shan Mountains in the process. While in Kashgar, he met and made friends with Francis Younghusband (the military explorer, and first Englishman to enter the Tibetan capital of Lhasa, in 1904-05), whom he greatly impressed with his linguistic abilities, he was fluent in seven languages, scientific understanding and artistic accomplishments. Indeed Younghusband was of the opinion that Hedin possessed all the qualifications required to be a scientific traveller. On his return to Europe Hedin concluded his formal studies in Berlin.

\section{The 1893-97 Expedition}

In 1893 Hedin undertook his first historic journey across Central Asia (Fig. 2, expedition route 2). From Tashkent he reached Kashgar by crossing the Pamir river, ignoring the warnings of undertaking a winter crossing during which temperatures dropped to $-38.3^{\circ} \mathrm{C}$. On the way he tried four times to climb the Mustagh Ata, and on temporarily losing his sight had to be led into Kashgar blindfolded.

He departed Kashgar in February 1895, with the primary 


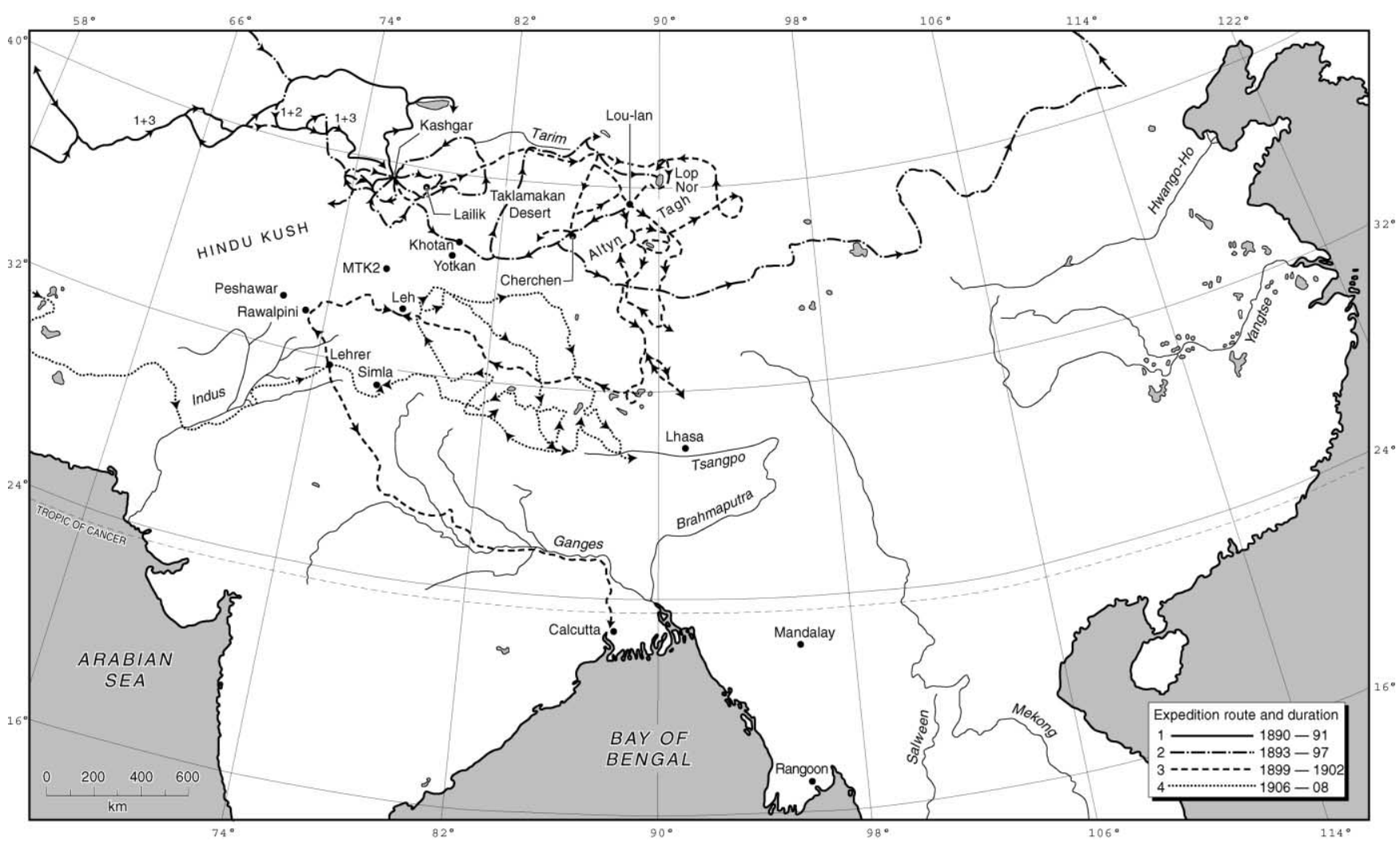

Fig. 2. Route map of Hedin's Central Asiatic excursions. 1: 1890-1891; 2: 1893-1897; 3: 1899-1902; 4: 1906-1908. The main exploratory excursions and geological collecting trips are excursions 2-4. Samples housed in Sweden (Swedish Museum of Natural History, Stockholm and Uppsala University), and described in this paper and on the spreadsheet are from excursions 2-4, and the Sino-Swedish expedition of 1927-35 (Fig. 3).

objective of crossing the Taklamakan desert, mapping its southwestern corner between the Yarkand and Khotan rivers, and then pushing on into Tibet. However, the small expedition of five men, eight camels, three sheep and two dogs ran out of water 15 days after leaving Merket. Despite rationing the last of their water, it was over five days before they reached the Khotan river and safety. Hedin's story of survival is remarkable, involving desperate attempts at digging for water at the camp sites, surviving a day-long sandstorm, abandoning equipment and resorting to quenching thirst by drinking oil from the primus stove, chicken's blood and camel's urine (mixed with vinegar and sugar). The delirious Hedin, on finally reaching the Khotan River found water when startled waterfowl took to the air. After drinking and regaining his strength, Hedin filled his boot with water and returned to aid one of his guides, while another was found by travelling merchants. Sadly, two guides, and all the animals barring one camel, perished in the desert. Hedin said of the journey that it "proved to be one of the most difficult I ever undertook in Asia." His vivid account of preparing the expedition and the ordeal in the Taklamakan desert appeared in 1898, published in volume one of Through Asia, although an excellent condensed account by Sylvia Volk is available at the following website http://www.ucalgary.ca/ chilton/SvenHedin.htm.

Undeterred by nearly losing his life, Hedin's second excursion, departing in December 1895, skirted the western edge of the Taklamakan desert, via the old Silk Road. Hedin purchased coins, manuscripts and other antiquities, many later identified as having come from the region's ancient capital of Yotkan (now known as Borasan), from local treasure hunters. Most of these objects are now housed and displayed in the Ethnological Museum in Stockholm. On hearing the stories from locals about mysterious lost cities in the heart of the desert, Hedin set off from Khotan heading to the northeast in search of relics.

At one site Hedin discovered wooden posts and a section of wall protruding from the sand. On examination of statues at the site, Hedin realised he had found a long-lost Buddhist civilisation. Conscious of the fact that he lacked the resources and archaeological expertise to pursue a full scientific survey, Hedin was content to map the site and leave the scientific examination of his finds to better qualified men. However, considering he was not a trained archaeologist or art historian, his observations were surprisingly perceptive, including the recognition of features characteristic and common to Indian, Greek and Persian cultures.

On returning to Khotan Hedin spent the next month working on his maps and notes before embarking on a short exploratory trip onto the Tibetan Plateau, crossing the border via the Arka Tag mountain chain and then travelling via Beijing and the Trans-Siberian railway to Sweden. 


\section{The 1899-1902 expedition}

With his fame as an explorer established, Hedin's reputation was further enhanced on this trip by the discovery of the lost city of Lou-lan. This expedition (Fig. 2, expedition route 3) was on a much larger scale than the previous two, financed in part by the King of Sweden and the millionaire Emmanuel Nobel, and was to last for nearly three years.

Hedin departed from the village of Lailik on the Yarkand river on September 5th, 1899. This was the first major expedition through the Taklamakan desert by boat. Hedin's primary objectives were to map the Yarkand, and its continuation the Tarim river, with his ultimate destination being the salt lake Lop-Nor situated in the heart of the desert, into which the rivers drained. He then hoped to extend the travel into eastern Tibet.

His fears on undertaking a river passage during winter were realised in early December when his boats became trapped by ice. However, despite the party not possessing a tent Hedin undertook a number of overland journeys from the boats. Over the next one-and-a-half months he travelled to the southern Silk Road town of Cherchen before heading northeastwards back into the Lop desert, and finding the ruins of an ancient settlement. This turned out to be the western frontier Chinese garrison town of Lou-lan (Fig. 2), obliterated by sands before 1224 when Marco Polo travelled through the Lop desert. Having surveyed and excavated the ruins, and found numerous wooden carvings with Indian writing and manuscripts with Chinese characters, Hedin recognised the town had been a flourishing community, sophisticated enough to support a school, hospital, post office and civil service, before falling to the Barbarians at the beginning of the fourth century.

Hedin then diverted his attention to the second objective of his expedition, a second trip into Tibet, attempting this time to become the first European to reach Lhasa (the 'forbidden city') for over 100 years. Through the failure of other attempts at this time, Hedin was aware that success could only be achieved by surprise and speed in order to deceive the Tibetan officials. He disguised himself as a native, and for several weeks, acted out the part of a servant in his own caravan. However, the vigilance of the Tibetans thwarted his progress some 150 miles, approximately 5 days travel, short of Lhasa. He was fortunate to be let off with a warning, as he might have been imprisoned or even executed, and ordered to leave. This he did by turning west over the mountains, and via Leh in Ladakh into British India. Hedin never again attempted to reach Lhasa, dismissing the city as 'hardly worth visiting'. However, Tibet had made a lasting impression, Hedin describing it as " ... the most stupendous upheaval to be found on the face of our planet".

\section{The 1906-08 Expedition}

Having spent the best part of a decade exploring and mapping Xinjiang, and occasionally crossing into Tibet,
Hedin wanted to mount a full-scale expedition into the southern part of the country. However, the prelude to his 1906, and possibly greatest expedition, was intricately entwined with British domestic and international political affairs.

Hedin arrived in India in May 1906, with the intention of crossing into southern Tibet. Having lost interest in the race to Lhasa, his sole objective was scientific mapping and exploration. A few months before this project had been granted approval by the British Government, with Lord Curzon, then Viceroy of India and a long time admirer of Hedin, arranging for three Indian surveyors to be specially trained in Dehra Dun to accompany him.

In the intervening time, a British Military Mission (under the leadership of Francis Younghusband) had entered Lhasa on diplomatic grounds, and negotiated the Anglo-Tibetan Convention. Meanwhile, in Britain a general election had resulted in the fall of Arthur Balfour's Conservative Government, to be replaced by Sir James Campbell-Bannerman's Liberals. Lord Minto also replaced Curzon as Viceroy, while a policy change and a clause in the Anglo-Tibetan Convention gave orders that no one was to enter Tibet, to be enforced by force if necessary. While Minto sympathised with Hedin he had no influence over the British Civil Service, who held the opinion that Hedin through his geological training, was intending to prospect for gold. Minto even suggested Hedin be accompanied by a military officer, but to Hedin's disgust John Morley, the new Secretary of State for India would not sanction it. Campbell-Bannerman also vetoed the idea, personally telegraphing Hedin in India.

Hedin regarded this as a promise broken by the British, and vowed to outmanoeuver them. Initially Hedin headed for Kashmir, halting at Srinagar to assemble a caravan. He then made for Ladakh, informing the authorities that he was heading north into Xinjiang, but planning to turn east into Tibet when out of sight. This move was foreseen by Whitehall, who issued orders that he was not to leave for Xinjiang without a valid passport (aware that one had not been granted). However, Hedin's influence within the Indian Government was extensive, and friends delayed the arrival of the telegram until he was beyond recall. Thus Hedin successfully outwitted the British Government, while the embargo placed on him was to guarantee the maximum acclaim to his unauthorised and extensive travels throughout Tibet.

Hedin's specific objective on this trip was to explore the valley of the Tsangpo (Upper Brahmaputra) river, which flows through southern Tibet, following it eastwards towards the town of Shigatze. Mapping his route in detail, he then travelled west finding its source, and also the sources of the Indus and Sutlej rivers in addition to the lakes of Rakas Tal and Mansarevar. Hedin also rediscovered the Transhimalayan mountain chain, lying parallel to the Himalayas in southern Tibet, regarding it "as the most striking of the world's geographical mysteries. Unknown the Transhimalaya had 


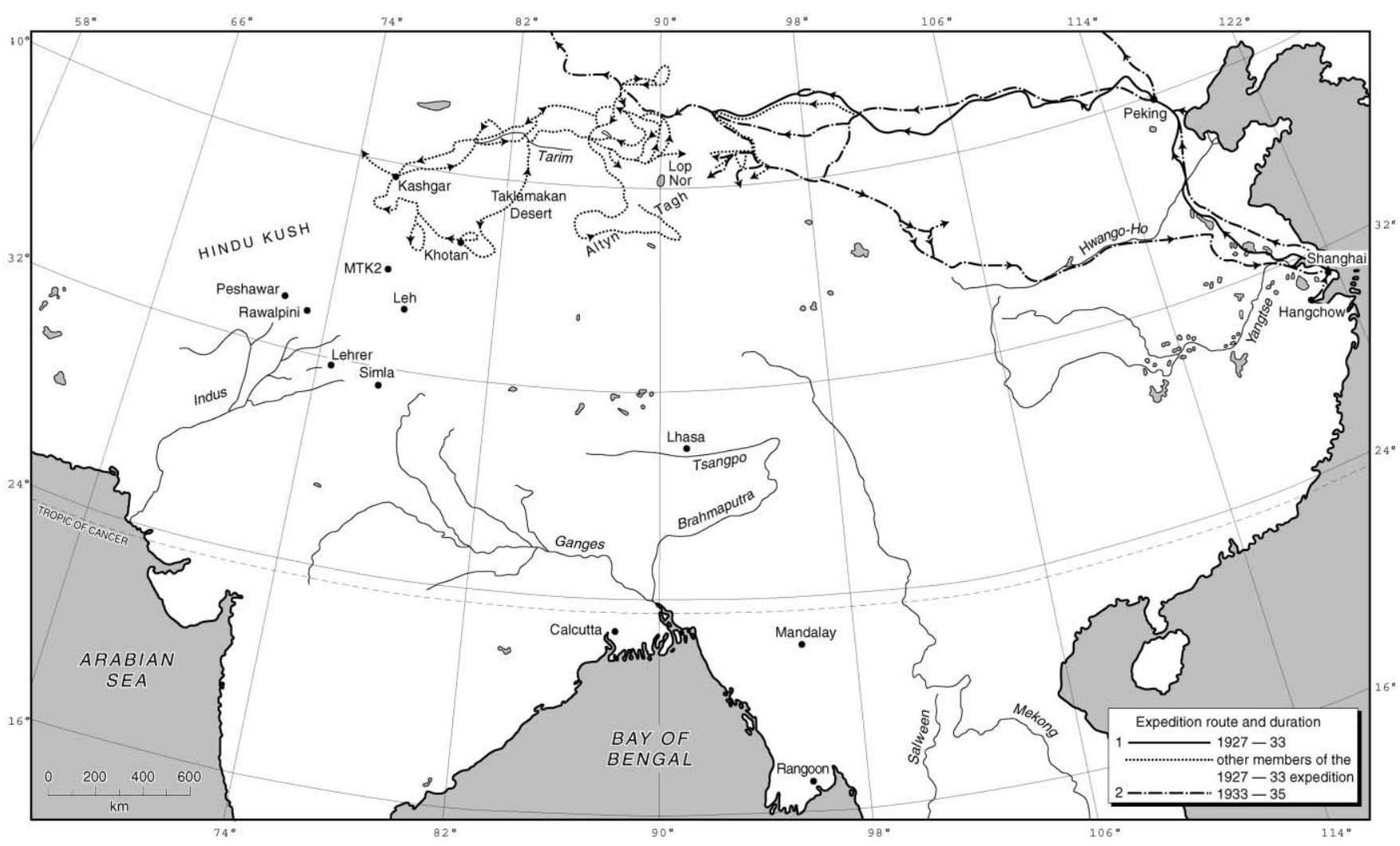

Fig. 3. Route map of the Sino-Swedish expeditions, 1927-1935. 1: Hedin, 1927-33; 2: Hedin 1933-35; 3: routes taken by Hedin's colleagues 1927-1935. Petrographic samples relating to these expeditions are deposited in the Institute of Earth Sciences, Uppsala University, Sweden. Palaeontological collections are deposited in the Institute of Geology and Palaeontology, Nanjing, China.

waited millions of years for my coming, I love it as my own possession".

In all he spent two years freely travelling across southern Tibet, mapping rivers, lakes and mountains, and collecting numerous geological specimens. On his return to Europe Hedin's study resulted in a comprehensive nine-volume report accompanied by a two-volume map report. In addition to impressing the scientific community, Hedin's results also impressed the British Government. Ironically, it then awarded him an honorary knighthood, conveniently forgetting the illicit nature of his journey. Other awards bestowed on Hedin included honorary degrees from both the universities of Cambridge and Oxford, and the Victoria Medal of the Royal Geographical Society, to go with the Gold Medal awarded in 1898. However, when questioned by British geographers Hedin felt antagonised by the establishment: 'for 150 years the English have owned India and yet done so little to explore Tibet that when a stranger comes and makes discoveries - in spite of their having done their utmost to keep him out - it is naturally exasperating for them'.

Hedin's vivid and exciting account of his travels in Tibet was published through the German firm Brockhaus, and translated from Swedish into several languages, selling in vast numbers (Hopkirk, 1980).

\section{Hedin's reputation declines}

At the outbreak of the First World War influential Germans invited Hedin on an official visit to the German armies at the Western Front. On his return Hedin wrote a sympathetic and favourable book of his impressions (Hedin, 1915). As a result, the Royal Geographical Society of London denounced the explorer as an enemy of the King and by special resolution the society struck Hedin's name from their role of honorary members. Ridiculed by many people during this time, one book published in 1916 satirized him, purportedly by 'Hun Sveden' (Hopkirk, 1980).

Hedin's increasing pro-German views enhanced strong political bias, and conspired to overshadow what had been his finest achievements. In retrospect his views are puzzling, considering he was part Jewish (and would continually remind people so). During the 1930s he openly supported the Nazis, partly because he saw Germany as a bulwark against the 'Asiatic Hordes', and partly because of his friendship with German leaders, notably Göring, and his long-standing reliance on his German publisher and the banks who financially supported his expeditions. 


\section{The 1927-35 (Sino-Swedish) Expeditions}

Having been castigated as a showman and a lightweight, Hedin successfully led a major Sino-Swedish expedition into Central Asia. The first expedition (1927-33, Fig. 3, expedition route 1) concentrated on Inner Mongolia and Xinjiang. At its time, this was the largest and most complex scientific expedition assembled. It was so big and diverse that the press nicknamed it the 'Travelling University'. When it set off into the desert its camel train was the largest in living memory.

For six years this huge undertaking by Swedish and Chinese scientists maintained a series of research stations that extended most of the way from the Caspian Sea to the Great Wall in the east. Stations were manned by a combination of specialists, including a geologist, meteorologist, philologist (collecting Asian vocabularies), zoologist and palaeontologist. Hedin's role was to patrol between isolated outposts, smoothing down local difficulties, dealing with officialdom and bringing the much needed supplies, money and encouragement. In itself, this was a huge task for a man then in his sixties, especially as he was suffering from gallstones and back pain requiring morphine injections. A tumour on his spinal cord was suspected, and he briefly took time off to visit a surgeon in Boston, USA. Fortunately, no operation was required, and he returned to the field where his exceptional talents of leadership and unquenchable energy were channelled into a worthwhile project. Now at the age of 69 , Hedin lead the second SinoSwedish expedition (1933-1935, Fig. 3, expedition route 2) in trucks and cars, testing the potential of the ancient Central Asian Silk Road as a motor track for the future.

During these expeditions, Hedin's Swedish colleagues, Birger Bohlin and Gerhard Bexell, worked mainly on the northeastern part of the Tibetan Plateau, along the Nanshan and Qaidam rivers, while Erik Norin and Nils Ambolt concentrated their work on the western side of the plateau and around the Quruq Tagh area (Fig. 3). Further north, in the Gobi desert, Nils Hörner and Parker Chen undertook a study of dune structures and water flow down the Etsingol in addition to work in the Nanshan Range and around the inland lake of Lop Nor (Hörner and Chen, 1935; Hörner, 1957). On his return to Europe Hedin set to work writing four initial parts (History of the Expedition in Asia 19271935, see Appendix B.3) of the 45 Reports that were eventually published.

Hedin's misjudged flirtations with power politics continued in 1936, making a speech at the opening of the Berlin Olympics and having the dubious honor of meeting Adolf Hitler, providing yet more ammunition for his detractors. This was despite his own criticisms of the anti-Semitic policies of the German National Socialist party (Hedin, 1937), which brought him into conflict with the German propaganda ministry. Hedin refused to bow to pressure to alter his text, and consequently Tyskland och världsfreden was never published in German.

\section{Assessing Hedin's contribution to asian exploration}

The demise of Hedin's reputation and his standing within the scientific community was, to a large extent, selfinflicted, although much is based on political bias (from his detractors), and foolishness (self-inflicted). However, leaving his political relationships aside, his scientific work clearly deserved more recognition than has been given to date. As a man, he was considered blunt, brazen, daring and flamboyant. He always craved to be the first European to set foot on any particular spot, and exulted in defeating all rivals, although in his attempts at the 'race' for Lhasa he was clearly a poor loser.

This contrasts with his great rival, the Hungarian-born British archaeological explorer Sir Aurel Stein (18621943), about whom Hedin commented when Stein was forced to turn back during one trip, "in a similar situation I should never have made such a decision. I should have continued through the desert. It might have been the death of me and my men ... but the adventure, the conquest of the unknown country, and the struggle against the impossible, have a fascination which draws me with irresistible force". It was common for Hedin to expose himself and his men to great danger, hardships and deprivation. On his first trip into the Taklamakan only one of his eight camels survived, and going into Tibet 10 out of his 12 horses perished, as did four of his seven camels and a native guide, while another was lucky to survive with the loss of both feet through frostbite. However, recollections from Eric Norin and Birger Bohlin, both of whom accompanied Hedin during the Sino-Swedish expeditions, recall him as a caring person, concerned for the welfare of his native guides.

Hedin's accomplishments are beyond question, even when judged on his mapping ability alone. Modern satellite remote sensing imagery of Central Asia confirms how accurate his ground mapping techniques were. His artistic legacy in recording many of the every day features of Asiatic and Tibetan life offer a valuable insight and detail of an age now long gone. As an explorer and adventurer his planning recognised the importance of previous studies. Hedin used the 13th century Venetian Marco Polo's Description of the World as a central Asiatic fixed point of reference. In the field, he always had four different editions of the work with him, as it contained excellent descriptions of conditions within the Gobi Desert.

Hedin's legacy is a unique data-base of maps, descriptions (archaeological, astronomical, meteorological), illustrations, photographs, specimens and antiquities available to researchers as a means of testing models which are difficult to verify first-hand from field observations. His success as a field scientist was the opening up of an unknown territory through discoveries and observations by criss-crossing the Tibetan Plateau, the Taklamakan and Gobi Deserts, providing masses of new information about social and physical features of the Asian heartland, and vividly and excitingly illustrating this through his writings. It is sad, that despite all 
R.F. Weinberg, O.R. Green / Journal of Asian Earth Sciences 20 (2002) 297-308

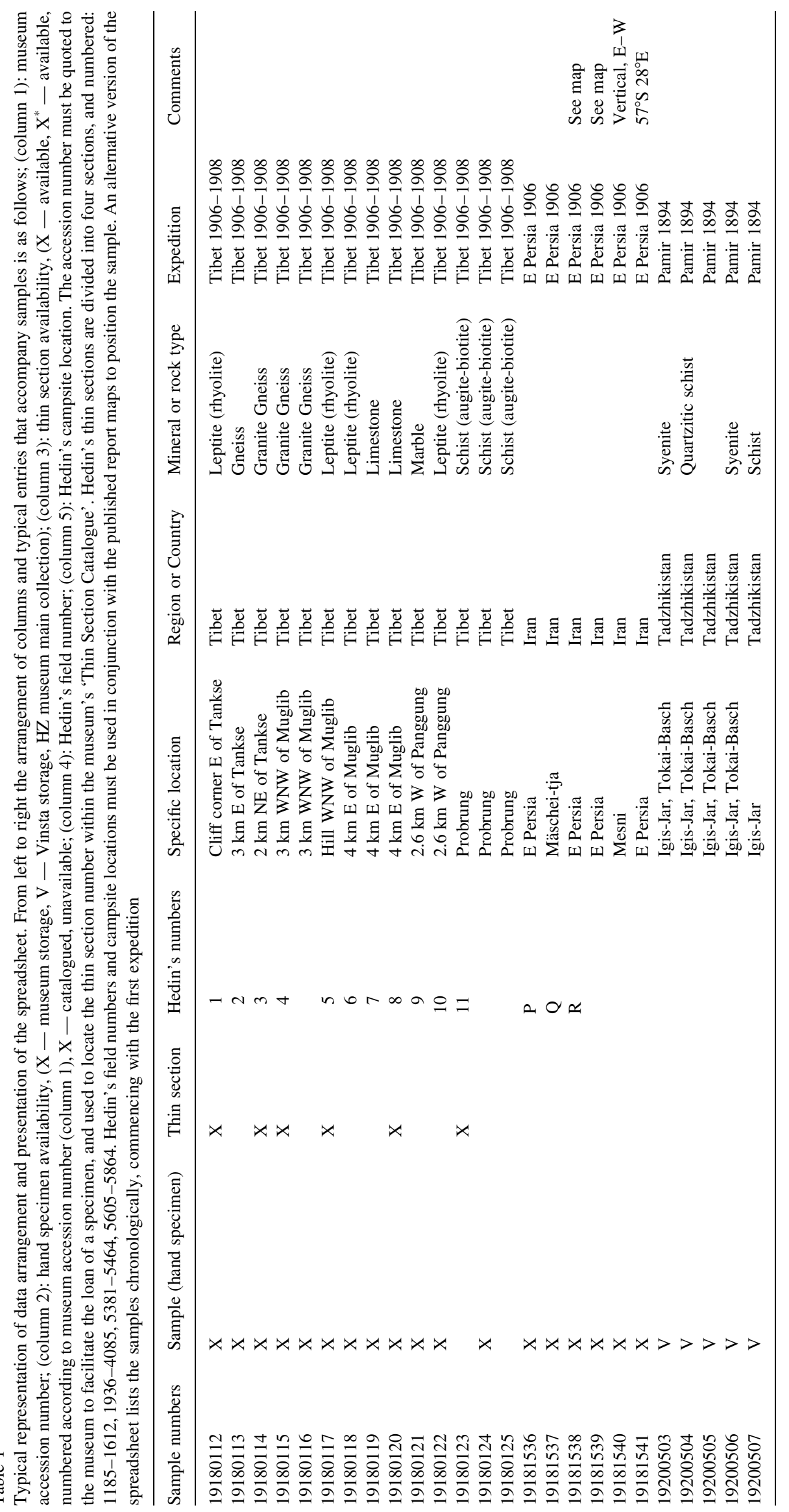


his success, his political failures ensured that by the time of his death in Sweden on November 26th in 1952, he was virtually a forgotten man, and reviled by many of those who had once honoured him.

\section{The spreadsheet database}

In this section we describe the availability of geological specimens, with particular reference to the expeditions commencing 1899 and 1906, and to which of Hedin's published scientific reports they relate. Unfortunately we have not found a published list for samples collected during the 1893-1897 expedition; however, these samples are available for examination. Through use of the spreadsheet database we demonstrate how to access the collections. Specimens collected by Hedin during the 1899 and 1906 expeditions have been described in two reports (see Appendix B for bibliographic details). The two key works will henceforth be referred to as: (1) Scientific Results and (2) Southern Tibet, respectively.

In order to utilise the spreadsheet, the reader will require copies of the map volumes from Scientific Results and Southern Tibet. Also useful, although not essential, is a list of the samples collected from 1899 to 1902 expedition, and published in volume 6, part 2 of the Scientific Results (Bäckström and Johansson, 1907), and the more comprehensive sample descriptions from 1906 to 1908 expedition published in volume 5 of Southern Tibet (Hennig, 1916). This volume consists of descriptions, some more detailed than others, of the individual samples, and is published in German. Also in volume 5, published in French, Douville (1915) provides a description and interpretation of the carbonates containing the Cretaceous agglutinated, conical test-shaped larger benthic foraminiferan, Orbitolina sp.

A catalogue of 2497 specimens from the expeditions commencing 1893, 1899 and 1906 is currently held at the Swedish Museum of Natural History, Stockholm (see Appendix A). Of the catalogued specimens, 2214 samples are available for examination and loan. The hand-specimens are relatively small, the majority no bigger than a few centimeters in diameter. The generally small specimen size prohibits their use in geochemical analyses, although they are suitable for the production of standard and polished thin sections for conventional optical and microprobe analysis. A total of 875 thin sections have also been catalogued, of which 57 are confirmed as missing. The preservation of Hedin's collection owes much to the professional ability and the manner in which Hedin undertook the original field logging of the information, and his attention to detail in creating a valuable research collection for experts to utilise.

A small portion of the spreadsheet is reproduced here (Table 1). The layout of the spreadsheet incorporates the specimen accession number given by the Museum (Column 1 , Table 1), the key number required in locating either hand- specimen or thin section. Each thin section is cross-referenced to the sample number in the museum catalogue, allowing for the rapid identification of the two. Sample and thin section availability are shown in columns 2 and 3 of Table 1. Hedin's field numbering system consisted of a numerical specimen number and the camp number, which is close to the point of collection. This data is presented in columns 4 and 5 (Table 1), and thus links Hedin's field number and sample provenance to his published map and the museum accession number. The year of collection is also indicated on the thin section label.

\section{The petrographic collection at Uppsala}

Samples collected by Hedin's collaborators during the Sino-Swedish (1927-1935) expedition are only preserved in the form of petrographic thin sections. These are available from the Institute of Earth Sciences, Uppsala University, Sweden (see Appendix A), where many of Hedin's coworkers were based. Data relating to these sections does not appear in our spreadsheet. Preliminary studies using this large collection were published in Reports for the Scientific Expedition to the North-Western Provinces of China under the leadership of Dr Sven Hedin. 1927-1935 — the SinoSwedish Expedition (see Appendix B for bibliographic details).

General reference to publications from these works in the following discussions will be shortened to Reports from the 1927-1935 Expedition.

\section{The Central Asian geological collections of Hedin}

Petrological specimens were collected by Hedin and his collaborators on all of his expeditions (see Figs. 2 and 3), and briefly documented in the three major reports detailed above.

\subsection{3-1897 Expedition: (Fig. 2, expedition route 2)}

During this expedition he collected 351 samples, of which 293 hand specimens and 139 thin sections are preserved in the collections in Stockholm. On the spreadsheet, these samples are divided into two groups: (1) Pamir and Tarim (1894-1895), and (2) Arka Tag and the road to Beijing. As a published list of samples collected during this expedition has not been found, specimens can only be generally located, matching the locality name on the spreadsheet to that indicated on one of Hedin's 11 route maps published in the first map volume of Southern Tibet. Additional route map data and notes on the geology can also be found in Hedin (1900).

\subsection{9-1902 Expedition: (Fig. 2, expedition route 3)}

From this expedition 818 samples were collected, of which 720 hand specimens and 321 thin sections are still 

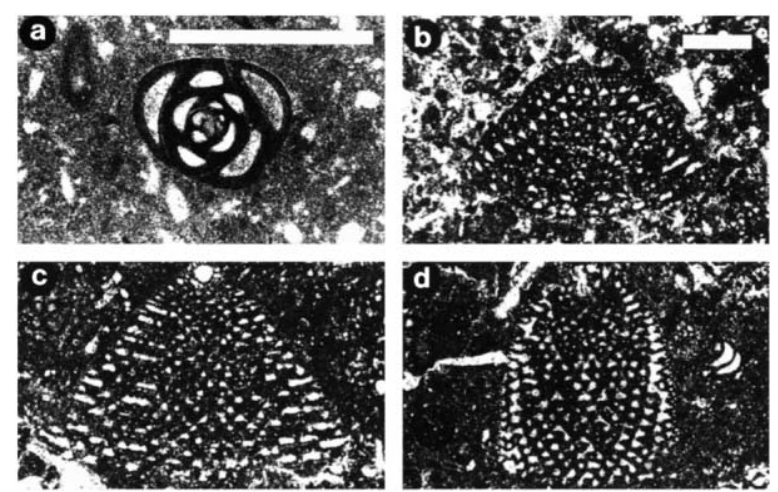

Fig. 4. Typical preservational examples of Cretaceous (Barremian-L. Albian) foraminifera rich limestones from the 1901 (a and b) and 1906 (c and d) expeditions. All views in plane polarised light. (a) Quinqueloculina sp., equatorial section, $\times 100$, sample no., 201382. (b) Orbitolina (Mesorbitolina) texana, $\times 40$, sample no. 201386. (c) Orbitolina (Conicorbitolina) conica, megalospheric form, $\times 40$, sample no., 180323. (d) Orbitolina (Neorbitolinopsis) conulus, $\times 40$, sample no. 180324. (b-d), axial sections. Scale bar equals $0.5 \mathrm{~mm}$. Samples deposited in the Swedish Museum of Natural History, Stockholm.

available. Bäckström and Johansson (1907) produced a geological map, and a list of samples (in Scientific Results, volume VI, part II - Geology). The map does not show individual sample locations, but indicates broad lithological distributions, and samples can be easily located by matching the camp number, from where the specimen was collected, to the location given in the map volumes of Scientific Results.

Limestones from the 1900 expedition contain poorly preserved molluscan and echinoderm fragments, while carbonates collected in 1901 contain a better preserved benthic foraminiferal assemblage. The assemblage is dominated by fragments of Orbitolina sp. and other smaller benthic agglutinated and calcareous forms, in addition to deformed cross-sections through echinoderm spines (Fig. $4 a, b)$.

\subsection{6-1908 expedition: (Fig. 2, expedition route 4)}

From this expedition 1313 samples were collected, of which 1194 hand specimens and 415 thin sections are preserved in Stockholm. The samples were described by Hennig (1916), in Southern Tibet, volume V. Their location can be found in the map volume of Southern Tibet. In this collection, there are several samples of the calc-alkaline, pre-collisional Transhimalayan granitoids, in addition to a number of peridotites and serpentinites from the IndusTsangpo Suture Zone, which marks the contact between the Indian and Asian plates. Eleven previously unsectioned limestones from the 1906 expedition have been examined. Six of these contain Orbitolina sp., with well-preserved examples of O. (Conicorbitolina) conica and O. (Neorbitolinopsis) conulus being present in the benthic assemblages (Fig. 4c,d), suggesting a late Albian or early Cenomanian age for some of the carbonates. Two examples of blueschist were collected by Hedin at camps 50 and 51, and described by Hennig (1916). One sample is a fine-grained schist containing glaucophane, while the other is a much coarser glaucophane-riebeckite-stillpnomelane-lawsonite rock. Blueschists are relatively uncommon crustal rocks that have been metamorphosed at low temperatures and high pressure. Where rapid burial to great depths and subsequent exhumation occurs, it is feasible that blueschists can be preserved within suture zones. Although blueschists from the Indus-Tsangpo Suture Zone have been known for many years (e.g. Honegger et al., 1989), continued debate surrounds their significance. Kapp et al., 2000 interprets them as exposures of the Banggong-Nujiang Suture Zone exhumed from depth below the Changthang block, and separating it from the Lhasa block to the south. Alternatively, they might be part of the Jinsha Suture Zone (e.g. Chang et al., 1986), which separates the Changthang block from the Kun-Lun Terrane to the north. A third interpretation sees the blueschists marking a suture separating two crustal fragments (one Gondwanan, one Cathaysian) now forming the Changthang block (Kidd et al., 1988).

\subsection{7-1935 Expeditions: (Fig. 3, Expedition routes 1 and 2)}

Geological work undertaken by Hedin and his co-workers is detailed in Reports from the 1927-35 Expedition. Unfortunately, the hand specimens cannot be traced, and unlike Hedin, the participating geologists did not publish a detailed list of the samples collected. As a consequence, the scientific value of this collection is severely reduced, as only a few locations of the thin sections can be accurately determined. Sections from three studies are summarised below.

(i) Western Tibet: Norin (1946) undertook extensive geological mapping in Western Tibet, and nearly all the sections described in Reports from the 1927-1935 Expedition are available in Uppsala. The 283 sections are numbered from 876 to 1159 , corresponding to the published data. However, the series is incomplete with 41 slides missing (numbers 891-899, 947-948, 964-967, 1004-1019, 1085-1094). Determining sample location is a timeconsuming process, requiring close study of the detailed map and report produced by Norin. The collection includes samples of leucite-bearing alkaline lavas from the plateau. Their presence was used to support the hypothesis that lithospheric mantle delamination occurred underneath the plateau, and is responsible for plateau uplift, extension and volcanism (Turner et al., 1993, 1996).

There are two known belts of alkaline lavas in Tibet. One in the northern part of the plateau, along the eastern KunLun (Arka Tagh), recognised by Hedin during his first and second expeditions, and described by Bäckström and Johansson (1907) as bronzite andesites, hornblende-biotite andesites and trachytoid andesites. The second belt was described by Norin (1946), under the section 'The Latites', 
p. 127 and Table XIII, p. 130, while their location is shown in fig. 29.

(ii) Quruq Tagh, Xinjiang: Norin also produced a volume of the Reports from the 1927-35 Expedition on the sedimentary sequence in the Quruq Tagh, north of the Tarim river, in Xinjiang (Norin, 1941). Of the 186 thin sections from this study in Uppsala only a few section numbers correspond to those mentioned in the report. The samples are divided into those belonging to the Charchak Series, the Qirgistan Series, the Qaraqizil Series (including limestones from the Yukkengol Formation), and the Quruq Tagh Series. The collection also includes tillites, spilitic breccias, doleritic greenstones and intrusive rocks.

(iii) Nanshan: Nearly 300 specimens from the Nanshan Mountains (the mountain chain east of the Altyn Tagh, Fig. 3) were collected by Bexell and Hörner between 1930 and 1932 and described by Du Rietz (1940). These include examples of the Nanshan ophiolites, peridotites (spinel harzburgites) and serpentinites (Yin and Nie, 1996). Unfortunately, of the sections described, only 88 collected by Bexell and 27 by Hörner are preserved at Uppsala. However, it is difficult to correlate the thin sections with the descriptions presented by Du Rietz (1940).

This paper does not cover the palaeontological results of the Sino-Swedish expedition, primarily because the fossil collections have been returned to China, and are now in Nanjing. Several papers describing the fossils have been published (e.g. on the invertebrate fossils, Troedsson, (1937 - trilobites); Bulman (1937 — graptolites, in Troedsson); and vertebrate fossils, Bohlin (Volumes VI.1 - VI.4 of the series)). Many fossils were named after expedition members (e.g. trilobites: Hedinaspis (Hedinia) regalis, Norinia convexa), a trend continued to this day with the foraminiferan Palorbitolinoides hedini (Cherchi and Schroeder, 1980).

\section{Summary}

Over a 40-year period, and four major expeditions into Central Asia, Sven Hedin and his colleagues collected a diverse range of geological specimens. The major repositories for the petrological collections are the Museum of Natural History, Stockholm, and the Institute of Earth Sciences, Uppsala University. A total of 3081 specimens from Hedin's expeditions are catalogued in these two institutions, with over $47 \%$ of the collection having thin sections. All the hand specimens from the 1927 to 1935 expedition examined in Uppsala, and a small number from Stockholm cannot be traced. This represents a total of $26.8 \%$ of the collection. However, only $6.3 \%$ of the thin sections are missing. The lack of awareness by contemporary Central Asiatic and Himalayan research workers of this collection is reflected in a number of enquiries and requests to use these specimens. However, considering the length of time since the specimens were collected, it is gratifying to report that so much of the collection $(89.5 \%)$ is still in existence in either the form of hand specimens or thin sections.

Although Hedin never considered himself to be a professional geologist, he was clearly an earth scientist of considerable merit, with professional forethought for succeeding generations of earth scientists. In parallel with his approach to archaeological and ethnological finds, Hedin clearly knew his limitations with petrological interpretations and enlisted the help of experts. However, he also realised the value of a collection in which location data had been adequately recorded in relation to a well-constrained base map. This was his forte as a field scientist. The demise of his international reputation, largely self-inflicted through his own political leanings, may have appeared justified at the time of his death in a post-war Europe coming to terms with stability. However, his legacy to the understanding of many aspects of Central Asia, including the regional geology, provides a fundamental starting point for any new study. The spreadsheet database described in this paper provides a means of accessing the geological collections of Sven Hedin and his colleagues. Specimens are available for study (see Appendix A), and both Swedish institutions are willing to loan material for the purposes of Central Asiatic and Himalayan research. Further information regarding Sven Hedin's life and work, and his personal archive comprising some 80,000 letters and his diaries, is now kept by Riksarkivet in Stockholm.

\section{Acknowledgements}

We thank Henrik Skogby and Dan Holtstam at Swedish Museum of Natural History, Stockholm, and the staff of the Institute of Earth Sciences, Uppsala University for permission to work and publish on the petrological collections of Sven Hedin, and hosting the spreadsheet on their website. Thanks also to Professor Zhou Zhiyi for information on the palaeontological collections housed in Nanjing Institute of Geology and Palaeontology, China. Sanna Törnemann of the National Museum of Ethnography, Stockholm, supplied the photograph of Sven Hedin used in Fig. 1. Jill Holmes provided information on the history and life of Sven Hedin, and Dave Sansom who skillfully drafted Figs. 2 and 3. Derek Siveter and Sam Turvey commented and improved on an earlier draft of the paper. Constructive reviews by Patrick Wyse Jackson and Bill Kidd greatly improved the manuscript.

\section{Appendix A. Collections information}

Curators: Dr Henrik Skogby and Dr Dan Holtstam, Swedish Museum of Natural History, Department of Mineralogy, Box 50007, Stockholm, S-104 05, Sweden, E-mail: henrik.skogby@nrm.se E-mail: dan.holtstam@nrm.se Tel: +46-8-519-540-00; Fax: +46-8-519-540-31. Curator 
Dr Per Nysten, Institute of Earth Sciences, Uppsala University, Uppsala, S-752 36, Sweden, E-mail: per.nysten@geo.uu.se. Tel: +46-18-471-2554; Fax: +4618-471-2591. Curator Dr Zhou Zhiyi, Nanjing Institute of Geology and Palaeontology, Academia Sinica, 39, E. Beijing Road, Nanjing, People's Republic of China 210008. E-mail: zyizhou@pub.jlonline.com, Tel: +86-257711556 or 7713534; Fax: +86-25-3357026.

For more information on Sven Hedin, and access to the spreadsheet consult the Department of Mineralogy, Swedish Museum of Natural History web site at http://www.nrm.se/ $\mathrm{mi} /$ welcome.html.en, and follow page links.

\section{Appendix B. Hedin's Central Asiatic reports}

\section{B.1. Scientific Results of a Journey in Central Asia 1899- 1902}

A text of six volumes, with a further two containing maps. Published between 1904 and 1907. Volume 1, The Tarim River (S. Hedin, 523p, 1904); Volume 2, Lop-Nor (S. Hedin, 717p, 1905); Volume 3, North and East Tibet (S. Hedin, 593p, 1907); Volume 4, Central and West Tibet (S. Hedin, 654p, 1907); Volume 5, part 1, Meteorology (N. Ekholm, 448p, 1907), part 2, Astronomical Observations (K. G. Olsson, 472p, 1907); Volume 6, part 1, Zoology (W. Leche, 69p, 1907), part 2, Geology (H. Bäckström and H. Johansson, 18p, 1907), part 3, Racial types from Western and Central Asia (S. Hedin, 4p, 86plts, 1907), Archaeology (K. Himly and A. Conrady, 191p, 1907). Maps I, 47 sheets; Maps II, 37 sheets and 27 facsimiles from the authors originals (A. Lagrelius). A section on Botany by G. Lagerheimetal, which should have been published as part 2 of volume 6 in 1907, appears not to have been produced. English summaries by Hedin of the expedition were published by the Geographical Journal (London) (Hedin, 1902, 1903, 1904).

\section{B.2. Southern Tibet 1906-1908}

Discoveries in former times compared to my own researches in 1906-1908. Published in nine volumes with an atlas of panoramas, and two maps between 1916 and 1922. Volume 1, Lake Manasarovar and the sources of the great Indian rivers. From the remotest antiquity to the end of the 18th century (S. Hedin, 293p, 1917); Volume 2, Lake Manasarovar and the sources of the great Indian rivers. From the end of the 18th century to 1913 (S. Hedin, 350p, 1917); Volume 3, Transhimalaya (S. Hedin, 369p, 1917); Volume 4, Kara-Korum and Chang-Tang (S. Hedin, 428p, 1922); Volume 5, Petrographiee und Geologie (A. Hennig, 212p 1916); Volume 6, part 1 Die meteorolgischen Beobachtungen (N. Ekholm, 133p, 1920); part 2 Les observations astronomiques calculées et rédigées (K.G. Olsson, 86p, 1918); part 3 Botany (C. H. Ostenfeld, 195p, 1922); Volume 7, History of exploration in the Kara-Korum moun- tains (S. Hedin, 605p, 1922); Volume 8, Chinese knowledge of Central Asia (456p, 1922), part 1 The Ts'ung-Ling mountains (S. Hedin and A. Herrmann); part 2 Die Westländer in der chinesischen Kartographie (A. Herrmann); part 3 Zwei osttürkische Manuskriptkarten (A. von Le Coq and A. Herrmann); part 4 Chinesische Umschreibungen von älteren geographischen (A. Herrmann); Volume 9, part 1 Journeys in eastern Pamir (1894-95) (S. Hedin, 85p, 1922); part 2 Osttürkische namenliste, mit Erklärungsversuchen (A. von Le Coq, 36p, 1922); part 3 Zur Geologie von Ost-Pamir (B. Asklund, 55p, 1922); part 4 Eine chinesische Beschreibung von Tibet, herausgegeben (E. Hänisch, 66p); Das Goldstromland im chinesich-tibetanischen Grenzgebiet (E. Hänisch, 64p, 1922); Maps I, Index, general and route maps (47 sheets, O. Kjellström and H. Byström, 1922); Maps II, Hypsometrical maps with special use of panoramas (52 sheets, H. Byström, 1922); Atlas of Tibetan Panoramas (S. Hedin, 10p, 1917). Hedin's English summary of this expedition appeared in the Geographical Journal (London) (Hedin, 1909).

\section{B.3. Reports for the Scientific Expedition to the North-} Western Provinces of China under the leadership of Dr Sven Hedin. 1927-1935 — the Sino-Swedish Expedition

This monumental work comprises over 45 separate publications, printed from 1937 to 1961. Four parts (Publications 23-26) were written by Hedin and entitled History of the Expedition in Asia 1927-1935. The other scientific reports were written by participants and experts, and assigned as parts to one of 11 volumes: I Geography, II Geodesy, III Geology, IV Palaeobotany, V Invertebrate Palaeontology, VI Vertebrate Palaeontology, VII Archaeology, VIII Ethnography, IX Meteorology, X Zoology, XI Botany. Geology is presented in volume III, which comprises eight parts: Publication 2, Vol III/1, E. Norin, 1937. Geology of Western Quruq tagh, Eastern T'ienshan, 194p; Publication 3, Vol III/2, B. Bohlin, 1937. Notes on some Palaeozoic localities in the Nan-shan SE of Tun-huang, 53p; Publication 10, Vol III/3, B. Bohlin, 1940. Notes on the hydrography of Western Kansu, 54p; Publication 12, Vol III/4, T. Du Rietz, 1940. Igneous rocks of Nanshan; a study in Caledonian igneous rocks, 117p; Publication 16, Vol III/6, E. Norin, 1941. Geologic reconnaissances in the Chinese T'ien-shan, 229p; Publication 29, Vol III/7, E. Norin, 1946. Geological explorations in Western Tibet, 214p; Publication 40, Vol III/5, N. Hörner, 1957. Some notes and data concerning Dunes and Sand Drift in the Gobi Desert, 40p; Publication 44, Vol III/8, B. Bohlin, 1960. Geological reconnaissances in Western Kansu and Kokonor, 79p. Publications of palaeontological parts presented in volumes IV, V and VI, were also published as part of Palaeontologica Sinica by the Geological Survey of China. There are 9 parts in these three volumes, authored by Bohlin, Troedsson, Frebold and Regnéll. 


\section{References}

Bäckström, H., Johansson, H., 1907. Geology. Hedin, S. (Ed.). Scientific Results of a Journey in Central Asia 1899-1902, Part II 6, 1-18.

Chang, C., Chen, N., Coward, M.P., Deng, W., Dewey, J.F., Gansser, A., Harris, N.B.W., Jin, C., Kidd, W.S.F., Leeder, M.R., Li, H., Lin, J., Liu, C., Mei, H., Molnar, P., Pan, Yun, Pan, Yusheng, Pearce, J.A., Shackleton, R.M., Smith, A.B., Sun, Y., Ward, M., Watts, D.R., Xu, Juntao, Xu, Ronghua, Yin, J., Zhang, Y., 1986. Preliminary conclusions of the Royal Society and Academia Sinica 1985 geotraverse of Tibet. Nature 323, 501-507.

Cherchi, A., Schroeder, R., 1980. Palorbitolinoides hedini n. gen, n. sp., grand foraminifère du Crétacé inférieur du Tibet méridional. Comptes Rendus de l'Academie des Sciences, Paris, Serie D, 291. , pp. 385-388.

Douville, H., 1915. Les calcaires a Orbitolines et a Radiolites du Thibet. In: Hennig, A., Petrographie und Geolgie von Prof. Dr Anders Hennig, Southern Tibet 1906-1908. In: Hedin, S. (Ed.), Discoveries in former times compared to my own researches in 1906-908, 5, pp. 145-147.

Du Rietz, T., 1940. Igneous rocks of the Nanshan. A study in Caledonian igneous rocks. Hedin, S. (Ed.). Reports from the Scientific Expedition to the North-Western provinces of China under the leadership of Dr Sven Hedin. The Sino-Swedish expedition, Publication 12. Geology. Part 4 3, 1-117 Thule, Stockholm.

Hedin, S., 1891. General Prschevalskijs forskningsresor i Centralasien, 455.

Hedin, S., 1897. with contributions from Himly, K., de Geer, G., Wille, N., Hemsley, W.B., Pearson, H.W., Bäckström, H., Hassenstein, B., 1900. Die geographisch-wissenschalftliche Ergebnisse meiner Reisen in Zentralasien, 1894-1897. Dr A. Petermanns Mitteilungen aus Justus Perthes Geographischer Anstalt, Herausgegeben von Prof. Dr A. Supan. Ergänzungsband. XXVII (Heft 131). pp. 1-399

Hedin, S., 1902. Summary of the results of Dr Sven Hedin's latest journey in Central Asia, 1899-1902. Geographical Journal 20 (2), 307-315.

Hedin, S., 1903. Three years exploration in Central Asia, 1899-1902. Geographical Journal 21 (3), 221-260.

Hedin, S., 1904. The scientific results of Dr Sven Hedin's last journey. Geographical Journal 24 (5), 524-545.

Hedin, S., 1909. Journeys in Tibet, 1906-1908. Geographical Journal 33 (4), 353-440.

Hedin, S., 1915. With the German Armies in the West. John Lane, London pp. 402.

Hedin, S., 1937. Tyskland och världsfreden. Medén, Stockholm pp. 368.

Hedin, S., 1939. Chiang-Kai-shek, Marskalk av Kina. Bonniers, Stockholm pp. 302.

Hennig, A., 1916. Zur Petrographie und Geologie von Prof. Dr Anders Hennig, Sudwest Tibet 1906-1908. In: Hedin, S. (Ed.), Discoveries in former times compared to my own researches in 1906-1908. vol. $5,1-212 \mathrm{pp}$.

Honegger, K., Le Fort, P., Mascle, G., Zimmermann, J.-L., 1989. The blueschists along the Indus Suture Zone in Ladakh, NW Himalaya. Journal of Metamorphic Petrology 7, 57-72.

Hopkirk, P., 1980. Foreign Devils on the Silk Road. John Murray. pp. 252.

Hörner, N.G., 1957. Some notes and data concerning Dune sands and sand drift in the Gobi Desert. Hedin, S. (Ed.). Reports from the Scientific Expedition to the North-Western provinces of China under the leadership of Dr Sven Hedin. The Sino-Swedish expedition, Publication 40. Geology. Part 5 3, 1-40.

Hörner, N.G., Chen, P.C., 1935. Alternating Lakes. Some river changes and lake displacements in Central Asia. Wallén, A. (Ed.). The Anniversary volume dedicated to Sven Hedin. Geografiska Annaler, 145-166.

Kapp, P.A., Yin, A., Manning, C.E., Murphy, M.A., Harrison, T.M., Spurlin, M., Ding, L., Deng, X., Wu, C., 2000. Blueschist-bearing metamorphic core complexes in the Qiangtang block reveal deep crustal structure of northern Tibet. Geology 28, 19-22.

Kidd, W.S.F., Pan, Y., Chang, C., Coward, M.P., Dewey, J.F., Gansser, A., Molnar, P., Shackleton, R.M., Sun, Y., 1988. Geological mapping of the 1985 Chinese-British (Xizang-Qinghai) Plateau Geotraverse route. Philosophical Transactions of the Royal Society of London, series A 327, 287-305.

Norin, E., 1941. Geologic reconnaissances in the Chinese Tien-shan. Hedin, S. (Ed.). Reports from the Scientific Expedition to the NorthWestern provinces of China under the leadership of Dr Sven Hedin. The Sino-Swedish expedition, Publication 16. Geology. Part 6 3, 1-229 Thule, Stockholm.

Norin, E, 1946. Geological explorations in Western Tibet. Hedin, S. (Ed.). Reports from the Scientific Expedition to the North-Western provinces of China under the leadership of Dr Sven Hedin. The Sino-Swedish expedition, Publication 29. Geology. Part 7 3, 1-214 Thule, Stockholm.

Troedsson, G.T., 1937. On the Cambro-Ordovician faunas of Western Quruqtagh, Eastern Tien Shan. In: Reports from the Scientific expedition to the north-western provinces of China under the leadership of Dr Sven Hedin. The Sino-Swedish expedition publication 4. V. Invertebrate Palaeontology 1. Palaeontologia Sinica. New Series B, Number 2. Whole Series Number 106. 1-74p + plates i-x. Plus appendix: Report on a collection of Graptolites from the Charchaq Series of Chinese Turkestan, by O. M. Bulman. pp. 1-6

Turner, S., Hawkesworth, C., Liu, J., Rogers, N., Kelley, S., van Calsteren, P., 1993. Timing of Tibetan uplift constrained by analysis of volcanic rocks. Nature 364, 50-54.

Turner, S., Arnaud, N., Liu, J., Rogers, N., Hawkesworth, C., Harris, N., Kelley, S., van Calsteren, P., Deng, W., 1996. Post-collisional, shoshonitic volcanism on the Tibetan plateau: implications for convective thinning of the lithosphere and the source of the ocean island basalts. Journal of Petrology 37, 45-71.

Yin, A., Nie, S., 1996. Phanerozoic palinspastic reconstruction of China and its neighboring regions. In: Harrison, T.M., Yin, A. (Eds.). The Tectonic Evolution of Asia. Cambridge University Press, Cambridge, pp. 442-485. 